\title{
Factors that Influence University Students' Attitude Towards Smoking Prohibition
}

\author{
Ryan Christian Prasetya ${ }^{1 *}$, M. Sih Setija Utami ${ }^{2}$ \\ ${ }^{1,2}$ Faculty of Psychology, Soegijapranata Catholic University, Semarang, Indonesia \\ *E-mail: ryanchrst@gmail.com
}

\begin{abstract}
This study objective was to examine factors that potentially influenced university students' attitude toward smoking prohibition in campus by improving the effectiveness of smoking policy. These altitudes are considered as important moderator in the process of adoption and compliance of smoking prohibition policy. This research is a quantitative descriptive study conducted amongst 100 students from the class of 2012 to 2015 in the Psychology Faculty of Soegijapranata Catholic University, Semarang. Seven factors were examined in this study which are significant others, culture, mass media, behavioral belief, smoking status, intention to quit smoking, and sex. Tools used in this study were questionnaire and scales designed by the researcher. The data were analyzed using nonparametric statistic to find out the relationship between each of seven hypothesized influencing factors and attitude towards the smoking prohibition policy. This study found factors that were influencing the attitude includes behavioral belief, sex, significant other, smoking status, and intention to quit smoking. While culture and mass media did not significantly influence the attitude.
\end{abstract}

Keywords: attitude, public policy, smoking prohibition, tobacco control, university students

\section{Introduction}

Tobacco smoking is one of major health concern in the world. Tobacco smoking has negative impacts on smokers themselves and also passive smokers. Every single cigarette consumed contains about 4.800 hazardous chemicals like nicotine, tar, carbon monoxide (CO), ammonia, cadmium, hydrogen cyanide, phenol, benzopyrene, and hydrocarbon compounds (Yahya, 2010). Research conducted by WHO estimated six millions of people died annually because of tobacco consumptions. This number includes 600,000 passive smokers (World Health Organization, 2015).

Many organizations have launched a movement to reduce the bad effects of smoking. In 2003, World Health Assembly agreed to adopt Framework Convention on Tobacco Control (FCTC) from WHO. The main focus of FCTC is to protect the current and future generations from the consequences of tobacco consumption and exposure that destroy health, social, environment, and economy (World Health Organization, 2015). In Indonesia, the government smoke-free areas policy. Act number 36 article 115 year 2009 and Government Regulation number 109 article 49 year 2012 stated that government and local government have to create smoke-free areas. Schools and Universities are public domains which government targets in the regulation to formulate and generate smoking policy and hence the focus of this study.

The effectiveness of the policy is influenced by many factors. As an important moderator in the process of adoption and compliance of smoking prohibition policy, factors that influence attitude should be examined.

Social and personality psychologist concluded attitude as a readiness, tendency, or pattern to react towards an object in certain ways (Azwar, 2015). 
Eagly and Chaiken (Albarracin, Johnson, Zanna, \& Kumkale, 2005) defined attitude as a psychological tendency that expressed in evaluation about specific object with favorable and unfavorable feeling. Attitude also can be defined as someone's beliefs and opinions about object, ideas, or other people (attitude object) (King, 2012). In short, attitude is someone's feeling about something; either it is positive or negative.

Theory of Reasoned Actions (TRA) stated attitude as a result of individual belief about probability of the outcome of behavior and the value of the outcome or it is called behavioral belief (Ajzen \& Fishbein, 2005). The more positive behavioral belief someone has, the more positive attitude towards the behavior someone does. In this case, the more positive behavioral belief towards smoking prohibition student possesses will make the student has more positive attitude and vice versa.

Azwar (2015) concluded human attitude formed by social interaction experienced by individuals. Individuals in their social interaction created certain patterns toward objects. The attitude formation affected by several factors. The first is personal experience, experience that individuals have would affect the way individuals react to an object. That experience will create positive or negative attitude to an object. Then, significant other which has a great influence on individuals' attitude because people tend to conform to their significant other. Culture also influences individuals attitude formation through reinforcement by society. Cultural background unconsciously aligned someone's attitude towards many objects. The different culture will form different attitude towards an object. Another factor is mass media. Mass media as a communication tool has a stake in forming individuals' opinions and beliefs. Strong suggestive message from mass media can form affective foundation about something so that it will form individuals' attitude towards the object. And the last one is education and religion institution. Those institutions put understanding and moral concept about good and bad in individuals; and emotion that individuals have.

Some research in tobacco control showed there were several different influencing factors of attitude towards smoking policy. Those research found the attitude influenced by smoking status, intention to quit smoking, and sex. The non- smoker group has more positive attitude towards smoking policy than the smoker group. Smokers who planned to quit in the next 30 days have more positive attitude than smokers who did not plan to quit. There is different attitude towards smoking policy between female and male participants. Female participants have more positive attitude than male participants (Rigotti, Regan, Moran, \& Wechsler, 2003; Chaaya, et al., 2013).

Based on those theories and researchers, this study was examined seven factors as influencing factors of university students' attitude towards smoking prohibition. The factors were significant others, culture, mass media, behavioral belief, smoking status, intention to quit smoking, and sex.

The purpose of this study was to take description of the factors that influence university students' attitude towards smoking prohibition.

\section{Methods}

Sample. This study was conducted in Psychology Faculty of Soegijapranata Catholic University, Semarang. The faculty has implemented smoking prohibition policy since January 2, 2014. The participants of this study were randomly assigned until reached the quota. The author assumed that minimum sample of the research should be 10 times of the research variable (Martono, 2010). In this case, the minimum sample should be 80 participants but this study used 100 participants to accommodate the probability of invalid data. The characteristics of the sample were the Faculty of Psychology students from classes of 2012 to 2015.

Research Design. This study was a quantitative descriptive research with one dependent variable and eight independent variables.

Instrument and Measurement. This research combined some theory and research findings. This used some part of factors that Azwar's which were significant other, culture and mass media and some factors from previous research which were smoking status, intention to quit smoking, and sex.

The measurements of this research included one questionnaire and three scales that were designed by the researcher. The questionnaire in this research consists of ten items. The data that were collected from this questionnaire were student status (faculty and class), sex, culture (ethnicity), mass media (cigarette advertisement, smoking 
warning, public service announcement), smoking status (active/passive, frequency), and intentions to quit smoking. Attitude towards smoking policy (positive or negative), significant others influence students' attitude towards smoking prohibition, and students' behavioral belief about smoking prohibition collected by using four-point Likert Scales.

The questionnaire in this study used multiple choice answer. The first question was about sex (male or female). Second, question about culture with six choices (Bataknese, Javanese, Papuan, Chinese, mixed, and other). Then, questions about the smoking status that consisted of two questions which were an active smoker or passive smoker, and smoking frequency (never smoke, occasionally, daily). The next questions about mass media exposure that measured by exposure frequency in a week (less than three times, three to six times, seven to ten times, and more than ten times) of cigarette advertising, smoking disadvantage warning, and public service announcement about smoking. The last item was about intention to quit smoking in the next thirty days for smoker participants (really want to quit, very likely, maybe, and does not want to quit).

The next part of the instrument was scale. There were three scales used in this study. The first scale was attitude towards smoking prohibition consisted of nine favorable and nine unfavorable items. The second scale was significant others scale consisted of three favorable and unfavorable items. And the last scale, behavioral belief scale contained three favorable and three unfavorable items.

The validity of the measurements was tested by correlating between each item and total item. After that, the value corrected used part whole correlation. The reliability of the instrument measured by Alpha-Conbranch coefficient to get the internal consistency. Based on the validity and reliability tests, the item number 5 was eliminated because it had low correlation with the total item was only .196.
Table 1.

Attitude Towards Smoking Prohibition Scale Items Validity

\begin{tabular}{|c|c|c|c|}
\hline \multirow[b]{2}{*}{$\begin{array}{c}\text { Item } \\
\text { Number }\end{array}$} & \multicolumn{3}{|c|}{ Corrected Item-Total Correlation } \\
\hline & $\begin{array}{c}\text { Attitude } \\
\text { Towards } \\
\text { Smoking } \\
\text { Prohibition }\end{array}$ & $\begin{array}{l}\text { Significant } \\
\text { Others }\end{array}$ & $\begin{array}{c}\text { Behavioral } \\
\text { Belief }\end{array}$ \\
\hline 1 & .494 & .712 & .422 \\
\hline 2 & .558 & .529 & .354 \\
\hline 3 & .597 & .726 & .586 \\
\hline 4 & .361 & .353 & .304 \\
\hline 5 & $196^{\mathrm{a}}$ & .597 & .546 \\
\hline 6 & .654 & .521 & .527 \\
\hline 7 & .490 & & \\
\hline 8 & .738 & & \\
\hline 9 & .415 & & \\
\hline 10 & .774 & & \\
\hline 11 & .550 & & \\
\hline 12 & .590 & & \\
\hline 13 & .758 & & \\
\hline 14 & .660 & & \\
\hline 15 & .671 & & \\
\hline 16 & .560 & & \\
\hline 17 & .670 & & \\
\hline 18 & .767 & & \\
\hline
\end{tabular}

${ }^{a}$ Invalid item that eliminated from the scale.

Table 2.

Scales Reliability

\begin{tabular}{cc}
\hline Scale & Alpha Coefficient \\
\hline Attitude Towards Smoking & .910 \\
Prohibition & .809 \\
Significant Others & .688 \\
Behavioral Belief & \\
\hline
\end{tabular}

\section{Procedure.}

In this study, the author used two preliminary instrument tests to examine the instrument's validity and reliability. The first was conducted to five respondents to measure the understandability of the instruments. The second instruments test was given to a class consisted of 57 university students. The data from the second test was used to measure the validity and reliability of the instruments. Then, invalid items eliminated and the scale given to the real participants.

The next procedure was to analyze data using nonparametric statistical method. This method used because the data did not normally distributed. Then, the collected data were analyzed by using statistical method as in Table 3. 
Table 3.

Statistical Analysis Method

\begin{tabular}{|c|c|c|}
\hline $\begin{array}{l}\text { Dependent } \\
\text { Variable }\end{array}$ & $\begin{array}{c}\text { Independent } \\
\text { Variable }\end{array}$ & Method \\
\hline \multirow{8}{*}{$\begin{array}{l}\text { University } \\
\text { student's } \\
\text { attitude } \\
\text { towards } \\
\text { smoking } \\
\text { prohibition }\end{array}$} & Significant others & $\begin{array}{c}\text { Spearman's } \\
\text { rank } \\
\text { correlation }\end{array}$ \\
\hline & Culture & $\begin{array}{l}\text { Kruskal- } \\
\text { Wallis }\end{array}$ \\
\hline & Mass media & $\begin{array}{c}\text { Kruskal- } \\
\text { Wallis }\end{array}$ \\
\hline & Behavioral belief & $\begin{array}{c}\text { Spearman's } \\
\text { rank } \\
\text { correlation }\end{array}$ \\
\hline & $\begin{array}{c}\text { Smoking status: } \\
\text { - } \quad \text { Active / } \\
\text { passive }\end{array}$ & $\begin{array}{l}\text { Mann- } \\
\text { Whitney }\end{array}$ \\
\hline & - Frequency & $\begin{array}{l}\text { Kruskal- } \\
\text { Wallis }\end{array}$ \\
\hline & $\begin{array}{l}\text { Intentions to quit } \\
\text { smoking }\end{array}$ & $\begin{array}{c}\text { Kruskal- } \\
\text { Wallis }\end{array}$ \\
\hline & Sex & $\begin{array}{c}\text { Mann- } \\
\text { Whitney }\end{array}$ \\
\hline
\end{tabular}

\section{Results}

The characteristics of the participants of this study were distributed as in this following table.

Table 4.

Research Participants

\begin{tabular}{cccccc}
\hline & \multicolumn{2}{c}{ Male } & \multicolumn{2}{c}{ Female } & \\
\cline { 2 - 4 } Class of & $\begin{array}{c}\text { Smoke } \\
\mathbf{r}\end{array}$ & $\begin{array}{c}\text { Non- } \\
\text { smoker }\end{array}$ & $\begin{array}{c}\text { Smok } \\
\text { er }\end{array}$ & $\begin{array}{c}\text { Non- } \\
\text { smoker }\end{array}$ & Total \\
\hline 2012 & 11 & 3 & 1 & 11 & 26 \\
2013 & 8 & 4 & 6 & 11 & 29 \\
2014 & 9 & 5 & 3 & 7 & 24 \\
2015 & 7 & 4 & 1 & 9 & 21 \\
Total & $\mathbf{3 5}$ & $\mathbf{1 6}$ & $\mathbf{1 1}$ & $\mathbf{3 8}$ & $\mathbf{1 0 0}$ \\
\hline
\end{tabular}

The total score of the attitude towards smoking prohibition scale was categorized into four groups: strongly agree (total score $\geq 68$ ); agree (total score 51-67); disagree (total score 34-50); strongly disagree (total score 17-33). The result showed most of the participants had positive attitude towards smoking prohibition (16\% strongly agree; $64 \%$ agree; $\overline{\mathrm{x}}=57.47)$. Students who don't smoke (mean rank $=65.76$ ) has more positive attitude than students who smoke (mean rank $=32.59$ ).
Table 5.

Attitude Towards Smoking Prohibition Scale Result

\begin{tabular}{cccc}
\hline Attitude & Score & $\begin{array}{c}\text { Participants } \\
\text { (n) }\end{array}$ & Percentage \\
\hline $\begin{array}{c}\text { Strongly } \\
\text { agree }\end{array}$ & 68 & 16 & $16 \%$ \\
Agree & $51-67$ & 64 & $64 \%$ \\
$\begin{array}{c}\text { Disagree } \\
\text { Strongly }\end{array}$ & $34-50$ & 14 & $14 \%$ \\
disagree & $17-33$ & 6 & $6 \%$ \\
Total & & $\mathbf{1 0 0}$ & $\mathbf{1 0 0 \%}$ \\
\hline
\end{tabular}

The significant others scale was categorized into four group; strongly influenced (total score 24), influenced (total score 18-23), uninfluenced (total score 12-17), and very uninfluenced (total score 611). The result of the scale showed most of the participants were not influenced by the significant others in forming their attitude towards smoking prohibition. Significant other has negative correlation to attitude towards smoking prohibition $(\rho(98)=-.471, p<.01)$. From this result could be concluded the more students uninfluenced by their significant other, the more positive their attitude towards smoking prohibition.

Table 6.

Significant Others Scale Result

\begin{tabular}{cccc}
\hline Attitude & Score & $\begin{array}{c}\text { Participants } \\
\text { (n) }\end{array}$ & Percentage \\
\hline Strongly & 24 & 2 & $2 \%$ \\
influenced & & 13 & $13 \%$ \\
Influenced & $18-23$ & 46 & $46 \%$ \\
Uninfluenced & $12-17$ & 46 & $39 \%$ \\
$\begin{array}{c}\text { Strongly } \\
\text { uninfluenced } \\
\text { Total }\end{array}$ & $6-11$ & 39 & $\mathbf{1 0 0 \%}$ \\
\hline
\end{tabular}

This study used cultural factor from the participants' ethnicity. The ethnicity of the participants divided into Bataknese, Javanese, Papuan, Chinese, mixed, and others. The number of Bataknese and Papuan were very limited, because of that they were excluded in the data analyses. The participants with mixed ethnicity had the most positive attitude $(\overline{\mathrm{x}}=59.63)$ compared to Javanese $(\overline{\mathrm{x}}=58.87)$, and Chinese $(\overline{\mathrm{x}}$ $=53.73)$.

In this study, mass media divided into three categories: (1) cigarette advertising; (2) smoking disadvantage warning; (3) public service announcement. Those media categorized into two groups which were media does support smoking (cigarette advertisement) and media doesn't support smoking (smoking warning and public 
service announcement). This study found the three of the mass media categories insignificantly influenced the student's attitude (cigarette advertising $\chi^{2}(3)=2.114, \mathrm{p}>.05$; smoking disadvantage warning $\chi^{2}(3)=5.990, \mathrm{p}>.05$; public service announcement $\left.\chi^{2}(3)=5.722, p>.05\right)$.

Behavioral belief was categorized into four groups. The group categorized by the score into very positive (total score 24 ), positive (total score 18-23), negative (total score 12-17), and very negative (total score 6-11). The data show most of the participants tend to have positive behavioral belief. This study found behavioral belief has positive correlation to attitude towards smoking policy $(\rho(98)=.863, \mathrm{p}<.01)$.

Table 7.

Behavioral Belief Scale Result

\begin{tabular}{cccc}
\hline $\begin{array}{c}\text { Behavioral } \\
\text { Belief }\end{array}$ & Score & Total & Percentage \\
\hline Very Positive & 24 & 39 & $39 \%$ \\
Positive & $18-23$ & 46 & $46 \%$ \\
Negative & $12-17$ & 13 & $13 \%$ \\
Very Negative & $6-11$ & 2 & $2 \%$ \\
Total & & $\mathbf{1 0 0}$ & $\mathbf{1 0 0 \%}$ \\
\hline
\end{tabular}

The $46(46 \%)$ of the participants in this study were active smokers and 54 (54\%) were not active smokers, $54(54 \%)$ of the participants never smoke, $18(18 \%)$ occasionally, and $28(28 \%)$ smoking in daily basis. From the 46 smokers, there were $9(9 \%)$ person who really wanted to quit smoking, 6 (6\%) very likely, $22(22 \%)$ maybe, and $9(9 \%)$ did not want to quit smoking in the next 30 days.

The analysis concluded students who don't smoke (mean rank $=65.76)$ has more positive attitude than students who smoke (mean rank $=32.59$ ). Based on the frequency, students who smoke daily (mean rank $=21.57$ ) had more negative attitude than students who rarely smoke (mean rank = 49.72), and never smoke at all (mean rank = 65.76). It can be implied that the more frequent a student smoke, the more negative their attitude towards smoking prohibition. Moreover, smokers who have higher intention to quit in 30 days has more positive attitude than smokers who have lower intention to quit $\left(\chi^{2}(3)=14.677, \mathrm{p}<.01\right)$.

The demographic factor which was very significantly influenced the attitude was sex $(\mathrm{U}=$ 634.00, p<.01). Female (mean rank $=63.06$ ) had more positive attitude towards smoking prohibition than male (mean rank $=38.43$ ) .

Table 8.

Statistical Analysis Result

\begin{tabular}{cccc}
\hline Factor & n & Result & Sig. \\
\hline $\begin{array}{c}\text { Significant others } \\
\text { Culture }\end{array}$ & 100 & $\rho(98)=-.471$ & $(\mathrm{p}<.01)$ \\
$\begin{array}{c}\text { Mass Media: } \\
\text { Cigarette ads. }\end{array}$ & 100 & $\chi^{2}(3)=3.578$ & $(\mathrm{p}>.05)$ \\
$\quad$ Warning & 100 & $\chi^{2}(3)=5.990$ & $(\mathrm{p}>.05)$ \\
$\begin{array}{c}\text { Public service } \\
\text { announcement }\end{array}$ & 100 & $\chi^{2}(3)=5.722$ & $(\mathrm{p}>.05)$ \\
$\begin{array}{c}\text { Behavioral Belief } \\
\text { Smoking status: }\end{array}$ & 100 & $\rho(98)=0.863$ & $(\mathrm{p}<.01)$ \\
$\begin{array}{c}\text { Active/passive } \\
\text { Smoking frequency } \\
\text { Intentions to quit } \\
\text { smoking }\end{array}$ & 100 & $\mathrm{U}=418.00$ & $(\mathrm{p}<.01)$ \\
$\quad$ Sex & 46 & $\chi^{2}(2)=43.073$ & $(\mathrm{p}<.01)$ \\
& 100 & $\mathrm{U}=634.00$ & $(\mathrm{p}<.01)$ \\
\hline
\end{tabular}

\section{Discussion \& Conclusion}

Discussion. The results of this study showed smoking prohibition in the Faculty of Psychology, Soegijapranata Catholic University has been adopted by most of students. Eighty percent $(80 \%)$ of the participants had positive attitude (strongly agree and agree) towards smoking prohibition.

There was significant negative correlation between significant other and attitude towards smoking prohibition. This result was different with Azwar's (2015) theory about conformity among individuals. Azwar concluded that people have tendency to conform in forming their attitude, but this study found the contrary. This result may be related to another variable which had stronger correlation; behavioral belief. As in Murnaghan, et al. (2009), behavioral belief has medium to high significant association to students' attitude. Students in this research more affected by their belief to the outcome of the policy than their significant other in forming their attitude toward smoking prohibition,

Students who don't smoke have more positive attitude than students who smoke. This finding supported the research conducted at a public university in the US (Butler, Rayens, Hahn, Adkins, \& Staten, 2011). In addition, research that compared national surveys from three periods in the US also found the similar result (Gilpin, Lee, $\&$ Pierce, 2004). 
Smokers in this research who had the intention to quit smoking in the next 30 days tend to have more positive attitude than smoking students who have no intention to quit. A study conducted by Doucet, Velicer, \& Laforge (2007) also has the similar result.

The difference between sexes in this study supported some previous researchs (Doucet, Velicer, \& Laforge, 2007; Gilpin, Lee, \& Pierce, 2004; Rashid, Manan, Yahya, \& Ibrahim, 2014). Those research also found female has more positive attitude towards smoking policy than male. This finding may be related to the numbers of the male smoker research participants.

The culture, which was defined as ethnicity, did not significantly influence the attitude. This may be related to the characteristic of the policy. The ethnicity of the participants does not seem to interfere with the attitude of smoking prohibition.

Another factor that did not significantly affect students' attitude is mass media. Mass media did not have significant influence because it doesn't have close relationship that influences someone's affection as Simons-Morton \& Farhat (2010) stated. Moreover, a research also found public service announcement does not effective (neutral) to promote anti-smoking behavior (Hong, Soh, Khan, Abdullah, \& Teh, 2013).

Conclusions. Based on this study, the factors that significantly $(\mathrm{p}<.01)$ influenced the university students' attitude towards smoking prohibition were behavioral belief, sex, significant others, smoking status, and intentions to quit smoking. Whereas, culture and mass media were not significantly (p>.5) influencing university students' attitude towards smoking prohibition.

There are also some limitations of this study. Firstly, this study was confined to a small population and should be addressed in the future study. It needs larger population and more participants to generalize this study's findings. Secondly, this study used nonparametric statistic. Nonparametric statistic somehow has lower statistical power than parametric one, so in the future research, one may consider using parametric test to eliminate this. Thirdly, this is a descriptive study, so it needs further research to examine these influencing factors closely. The factors need to be analyzed with qualitative research in the future to get a deeper understanding of the influencing factors.

\section{References}

Ajzen, I., \& Fishbein, M. (2005). The Influence of Attitudes on Behavior. in D. Albarracin, B. T. Johnson, \& M. P. Zanna (eds.), The Handbook of Attitudes, 173-221. Mahwah: Lawrence Erlbaum Associates.

Albarracin, D., Johnson, B. T., Zanna, M. P., \& Kumkale, G. T. (2005). Attitudes: Introduction and Scope. In D Albarracin, B. T. Johnson, \& M. P. Zanna (Eds..), The Handbook of Attitudes, 3-19. Mahwah: Lawrence Erlbaum Associates.

Azwar, S. (2015). Sikap Manusia: Teori dan Pengukurannya (2 ed.). Yogyakarta: Pustaka Pelajar.

Butler, K. M., Rayens, M. K., Hahn, E. J., Adkins, S. M., \& Staten, R. R. (2011). Smoke-Free Policy and Alcohol Use Among Undergraduate College Students. Public Health Nursing, 29(3), 256-265. doi:10.1111/j.15251446.2011.01000.x

Chaaya, M., Alameddine, M., Nakkash, R., Afifi, R. A., Khalil, J., \& \& Nahhas, G. (2013). Students' Attitude and Smoking Behaviour Following the Implementation of A University Smoke-free Policy: A Cross-sectional Study. BMJ Open, 3, 1-8. doi:10.1136/bmjopen-2012002100

Doucet, J. M., Velicer, W. F., \& Laforge, R. G. (2007). Demographic Differences in Support for Smoking Policy Interventions. Addictive Behaviors, 32, 148-157. doi:10.1016/j.addbeh.2006.04.003

Gilpin, E. A., Lee, L., \& Pierce, J. P. (2004). Changes in population attitudes about where smoking should not be allowed: California versus the rest of the USA. Tob Control, 13, 38-44. doi:10.1136/tc.2003.004739

Hong, Y. H., Soh, C. H., Khan, N., Abdullah, M. M., \& Teh, B. H. (2013). Effectiveness of Anti-Smoking Advertising: The Roles of Message and Media. International Journal of Business and Management, 8(19), 55-62. doi:10.5539/ijbm.v8n19p55

King, L. A. (2012). Psikologi Umum: Sebuah Pandangan Apresiatif (Vol. 2). (B. Marwensdy, Penerj.) Jakarta: Salemba Humanika.

Martono, N. (2010). Statistika Sosial: Teori dan Aplikasi Program SPSS. Yogyakarta: Gava Media.

Murnaghan, D. A., Blanchard, C., Rodgers, W., Rosa, J. L., Macquarrie, C., Maclellan, D., \& Gray, B. (2009, October). The influence of student-level normative, control and behavioral beliefs on staying smoke-free: An application of Ajzen's theory of planned behavior. Addiction Research and Theory, 17(5), 469-480. doi:10.1080/16066350802011649

Rashid, A., Manan, A. A., Yahya, N., \& Ibrahim, L. (2014, October). The Support for Smoke Free Policy and How It Is Influenced by Tolerance to Smoking - Experience of a Developing Country. PLOS ONE, 9(10), 1-7. doi:10.1371/journal.pone.0109429

Rigotti, N. A., Regan, S., Moran, S. E., \& Wechsler, H. (2003). Students' Opinion of Tobacco Control Policies 
Recommended for US Colleges: A National Survey. Tobacco Control, 12, 251-256. doi:10.1136/tc.12.3.251

Simons-Morton, B., \& Farhat, T. (2010). Recent Findings on Peer Group Influences on Adolescent Substance Use. The Journal of Primary Prevention, 31(4), 191-208. doi:10.1007/s10935-010-0220-x

World Health Organization. (2015). WHO Global Report on Trends in Prevalence of Tobacco Smoking 2015. Geneva: World Health Organization.

Yahya, A. F. (2010). Menaklukkan Pembunuh No. 1: Mencegah dan Mengatasi Penyakit Jantung Koronener Secara Cepat dan Tepat. Bandung: Qanita, PT Mizan Digital Publishing. 